Jurnal Ilmiah Pembelajaran Sekolah Dasar

Volume 1 Nomor 2 - Agustus 2019,e-ISSN 26560402

Available online at:http://ojs.uho.ac.id/index.php/jipsd

\title{
PENERAPAN MODEL PEMBELAJARAN KOOPERATIF TIPE GROUP INVESTIGATION (GI) DALAM MENINGKATKAN HASIL BELAJAR IPS SISWA MATERI SUMBER DAYA ALAM DI KELAS IV SDN TINENGI
}

\author{
Annas $^{1)}$, I Ketut Suardika ${ }^{1)}$, La Ode Rafiuddin ${ }^{1)}$ \\ ${ }^{1)}$ Jurusan Pendidikan Guru Sekolah Dasar \\ FKIP Universitas Halu Oleo \\ email: annass.pjj@gmail.com
}

\begin{abstract}
Abstrak: Tujuan dari penelitian ini adalah untuk meningkatkan hasil belajar siswa kelas IV SDN Tinengi pada mata pelajaran IPS materi Sumber Daya alam melalui model pembelajaran Kooperatif tipe Group Investigation (GI). Prosedur penelitian yaitu; (a) perencanaan (planning), (b) pelaksanaan tindakan (action), (c) observasi dan evaluasi (observation and evaluation), dan (d) refleksi (reflection). Jenis data yaitu data kualitatif dan data kuantitatif. Data kualitatif diperoleh melalui lembar observasi sedangkan data kualitatif melalui tes hasil belajar. Hasil analisis penelitian menunjukkan, penggunaan model pembelajaran kooperatif tipe Group Investigation (GI) dapat meningkatkan hasil belajar IPS siswa kelas IV SDN Tinengi Kabupaten Kolaka. Hal ini terlihat dari ketuntasan hasil belajar siswa sebelum penerapan model pembelajaran Kooperatif tipe Group Investigation hanya 20 siswa yang tuntas dari 30 siswa atau sebesar $66,67 \%$. Pada siklus I siswa yang tuntas 20 siswa atau sebesar $66,67 \%$ dan yang tidak tuntas berjumlah 10 siswa atau 33,33\%. Pada siklus II siswa yang tuntas berjumlah 27 siswa atau sebesar $90 \%$ dan yang belum tuntas berjumlah 10 siswa atau sebesar $10 \%$. Aktivitas mengajar guru pada siklus I pertemuan pertama sebesar $66,67 \%$ dan pertemuan kedua sebesar $83,3 \%$ sedangkan pada siklus II pertemuan pertama sebesar $100 \%$ dan pertemuan kedua sebesar $100 \%$. Aktivitas belajar siswa pada siklus I pertama sebesar $66,67 \%$ dan pertemuan kedua sebesar $83,3 \%$ sedangkan pada siklus II pertemuan pertama sebesar $100 \%$ dan pertemuan kedua sebesar $100 \%$.
\end{abstract}

Kata Kunci: Model Pembelajaran, Group Investigation, Hasil Belajar

Abstract: The purpose of this research was to improve the students' learning outcomes at SDN Tinengi at Class IV in Social Science subjects for the Natural Resources materials through the Cooperative learning model of the Group Investigation (GI) type. Research procedures were (a) planning (planning), (b) implementing actions (actions), (c) observation and evaluation (observation and evaluation), and (d) reflection (reflection). The types of data were qualitative and quantitative data. Qualitative data was obtained through observation sheets while qualitative data was obtained through learning outcomes tests. The results of the research analysis showed that the use of Group Investigation (GI) type can improve the students' learning outcome in social science subject at SDN Tinengi, Kolaka Regency in Class IV. It can be seen from the completeness of students' learning outcomes before the implementation of the Group Investigation type. In the first cycle, there were only 20 students $(66.67 \%)$ who achieved the target from 30 students and 10 (33.33\%) students who did not achieve the target. In the second cycle, there were 27 students who achieved the target or $90 \%$ and 10 students who did not achieved the target or 10\%. Teacher's teaching activities in the first meeting of cycle I were $66.67 \%$ and the second meeting was $83.3 \%$ while in the cycle II at the first meeting was $100 \%$ and in the second meeting was $100 \%$. Students' learning activities in the first meeting of cycle II were $66.67 \%$ and the second meeting were $83.3 \%$ while in the cycle II at the first meeting was $100 \%$ and the second meeting was $100 \%$.

Keywords: Learning Model, Group Investigation Type, Learning Outcomes 
Jurnal Ilmiah Pembelajaran Sekolah Dasar

Volume 1 Nomor 2 - Agustus 2019,e-ISSN 26560402

Available online at:http://ojs.uho.ac.id/index.php/jipsd

\section{Pendahuluan}

Proses pembelajaran yang berkualitas dipengaruhi oleh beberapa faktor antara lain: keterampilan mengajar guru, lingkungan belajar siswa, media pembelajaran yang digunakan oleh guru untuk menyampaikan materi pembelajaran, cara guru memotivasi siswa agar belajar dengan baik serta strategi dan model pembelajaran yang diterapkan oleh guru dalam kelas. Proses pembelajaran dan hasil belajar siswa tidak hanya ditentukan oleh sekolah, pola dan struktur serta isi kurikulum, tetapi yang paling penting adalah kemampuan guru dalam membelajarkan dan membimbing siswa.

Salah satu faktor yang sangat mendukung keberhasilan guru dalam mengelola pembelajaran adalah kemampuan guru dalam menguasai dan menerapkan model atau metode pembelajaran. Sebagian besar yang dilakukan oleh guru tidak lain dari pada menyajikan pengetahuan jadi yang harus diketahui dan dihafalkan oleh siswa. Iklim pembelajaran semacam ini terjadi pula dalam proses pembelajaran IPS. Kondisi pembelajaran IPS di sekolah belum mampu memberikan sesuatu yang bermakna bagi siswa. Fenomena seperti yang dikemukakan tersebut di atas sama dengan proses pembelajaran yang berlangsung pada SDN Tinengi Kabupaten Kolaka. Dalam praktek pembelajaran yang dilakukan oleh guru, masih banyak didominasi oleh guru. Apa yang dilakukan oleh guru adalah sekedar memindahkan atau mentrasfer pengetahuan dari guru kepada siswa, dengan buku sebagai satusatunya sumber belajar. Kedaan seperti ini membuat siswa jenuh, pasif, dan tidak menantang siswa untuk berpikir. Kondisi belajar seperti ini berdampak pada hasil belajar siswa.

Berdasarkan observasi awal yang dilakukan pada semester ganjil tahun pelajaran 2015/2016 pada siswa kelas IV SDN Tinengi diketahui bahwa hasil belajar IPS siswa kelas IV khususnya materi sumber daya alam masih tergolong rendah yang ditunjukkan dengan hasil ulangan harian siswa kelas IV belum tuntas sebanyak 14 siswa atau sebesar 50\% dan 14 siswa atau sebesar 50\% telah tuntas. Sementara itu, Kriteria Ketuntasan Minimal (KKM) yang ditetapkan di sekolah yaitu minimal $80 \%$ siswa memperoleh nilai $\geq 65$.

Sebagian siswa masih sulit dalam mempelajari materi ini, disebabkan guru mengajar cenderung menggunakan pendekatan pembelajaran konvensional. Pada pendekatan ini, cara guru mengajar dengan satu arah, akibatnya keterlibatan/aktivitas siswa kurang dalam proses pembalajaran, siswa cenderung pasif, pembelajaran terpusat pada guru, sehingga dapat dipastikan kondisi ini mengakibatkan daya serap dalam memahami materi menjadi rendah.

Dalam upaya untuk meningkatkan hasil belajar IPS materi sumber daya alam pada siswa kelas IV SDN Tinengi, maka penulis menganggap perlu untuk melakukan penelitian tindakan kelas untuk memperbaiki proses pembelajaran. Salah satu model pembelajaran yang digunakan adalah model pembelajaran kooperatif tipe Group Investigation. Model pembelajaran kooperatif tipe Group Investigation dalam menyajikan materi sumber daya alam merupakan suatu model yang diharapkan dapat memberi peran yang aktif dan motivasi kepada siswa agar mereka mempelajari dengan sungguhsungguh materi yang diajarkan. Model ini melibatkan lebih banyak siswa dalam menelaah materi yang tercakup dalam suatu pembelajaran dan mengecek pemahaman mereka terhadap isi pembelajaran tersebut.

Berdasarkan uraian di atas, maka penulis terdorong untuk melakukan suatu penelitian dalam bentuk penelitian tindakan kelas dengan judul: "Penerapan Model Pembelajaran Kooperatif Tipe Group Investigation (GI) dalam Meningkatkan Hasil Belajar Siswa pada Mata Pelajaran IPS Materi Sumber Daya Alam di Kelas IV SDN Tinengi Kabupaten Kolaka".

Hasil penelitian yang dilakukan oleh Haninu, (2010) yang menyimpulkan bahwa penerapan model pembelajaran kooperatif tipe Group Investigation dapat meningkatkan hasil belajar IPS pada siswa kelas IV SD Negeri 4 Poasia. Persentase ketuntasan hasil belajar siswa pada siklus I sebesar $60 \%$ dan pada siklus II sebesar 85\% yang menunjukkan telah mencapai KKM yang ditetapkan di sekolah yaitu minimal 80\% siswa meperoleh nilai minimal 65 .

Hasil penelitian yang dilakukan oleh Surina, (2010) yang menyimpulkan bahwa penerapan model pembelajaran kooperatif tipe Group Investigation dapat meningkatkan hasil belajar siswa materi Sumber Daya Alam di kelas IV SD Negeri 2 Mowewe. Persentase ketuntasan hasil belajar siswa pada 
siklus I sebesar 56\% dan pada siklus II sebesar $86 \%$ yang menunjukkan telah mencapai KKM yang ditetapkan di sekolah yaitu minimal 80\% siswa meperoleh nilai minimal 65 .

Model pembelajaran kooperatif tipe Group Investigation dirancang secara matang dan dilaksanakan secara tepat diharapkan dapat mendorong siswa lebih dapat meningkatkan persiapan dalam menerima pelajaran. Peningkatan motivasi belajar siswa juga diharapkan membawa dampak positif yaitu peningkatan hasil belajar siswa.

Masalah dalam penelitian adalah apakah model pembelajaran kooperatif tipe Group Investigation (GI) dapat meningkatkan hasil belajar IPS siswa pada materi sumber daya alam di kelas IV SDN Tinengi?. Tujuan penelitian adalah hasil belajar siswa kelas IV SDN Tinengi pada mata pelajaran IPS materi Sumber Daya alam melalui model pembelajaran Kooperatif tipe Group Investigation (GI). Penelitian ini diharapkan dapat memberikan manfaat bagi guru, siswa, sekolah dan penelitian lainnya.

\section{Metode Penelitian}

Jenis penelitian ini adalah penelitian tindakan kelas (classroom action research) berdasarkan "naturalistickualitatif". Penerapan penelitian tindakan di kelas diharapkan akan mampu mendorong guru memiliki kesadaran diri melakukan refleksi dan kritik diri terhadap aktivitas pembelajaran yang diselenggarakannya. Penelitian ini telah dilaksanakan pada semester ganjil tahun pelajaran 2016/2017 bertempat di SDN Tinengi dengan jumlah siswa 29 orang yang terdiri dari 14 siswa laki-laki dan 15 siswa perempuan. Faktor yang diteliti dalam penelitian ini adalah 1) faktor siswa, 2) Faktor guru dan faktor 3) hasil belajar. Penelitian Tindakan Kelas ini dilaksanakan dalam 2 (dua) siklus. Adapun prosedur penelitian tindakan ini meliputi: (1) Perencanaan, (2) Pelaksanaan Tindakan, (3) Observasi dan Evaluasi, dan (4) Refleksi dalam setiap siklus. Jenis data yaitu data kualitatif dan data kuantitatif. Data kualitatif diperoleh melalui observasi, menggunakan lembar observasi sedangkan data kuantitatif diperoleh melalui tes setiap akhis siklus tindakan

Analisis data dalam penelitian ini adalah menggunakan statistik deskriptif untuk menghitung dan mendeskripsikan nilai siswa, rata-rata nilai siswa, ketuntasan belajar, keberhasilan aktivitas mengajar guru dan keberhasilan aktivitas belajar siswa.

a. Menentukan Nilai Siswa

Nilai siswa ditentukan berdasarkan skor yang diperoleh siswa pada tes yang dilakukan dengan rumus:

$$
\text { Nilai Siswa }=\frac{\text { SkorPerolehan Siswa }}{\text { Skor Maksimum }} \times 100 \quad \text { (Suparno, 2008, p.80) }
$$

b. Menentukan ketuntasan belajar

1) Ketuntasan Individu

Ketuntasan individu siswa ditentukan berdasarkan nilai yang diperoleh pada setiap siklus. Siswa dikatakan belajar tuntas jika nilai yang diperoleh siswa adalah $\geq 6,5$ sesuai KKM yang ditetapkan sekolah.

2) Ketuntasan Klasikal

Ketuntasan klasikal ditentukan berdasarkan persentase ketuntasan individu siswa pada setiap siklus pembelajaran dengan rumus sebagai berikut.

$$
\% \text { tuntas }=\frac{\sum f i}{n} \times 100 \%
$$

Dengan :

$\mathrm{n}: \quad$ Jumlah siswa secara keseluruhan

$\sum f i$ : Jumlah siswa pada kategori ketuntasan belajar

Ketuntasan klasikal tercapai jika minimal $80 \%$ siswa telah mencapai ketuntasan individual. 


\section{Hasil Penelitian}

\section{Hasil Belajar Siswa}

Hasil analisis penelitian menunjukkan, penggunaan model pembelajaran kooperatif tipe Group Investigation (GI) dapat meningkatkan hasil belajar IPS siswa kelas IV SDN Tinengi Kabupaten Kolaka. Hal ini terlihat dari ketuntasan hasil belajar siswa sebelum penerapan model pembelajaran Kooperatif tipe Group Investigation hanya 20 siswa yang tuntas dari 30 siswa atau sebesar 66,67\%. Pada siklus I siswa yang tuntas 20 siswa atau sebesar 66,67\% dan yang tidak tuntas berjumlah 10 siswa atau $33,33 \%$. Pada siklus II siswa yang tuntas berjumlah 27 siswa atau sebesar $90 \%$ dan yang belum tuntas berjumlah 10 siswa atau sebesar $10 \%$.

\section{Aktivitas Mengajar Guru}

Aktivitas mengajar guru pada siklus I pertemuan pertama sebesar $66,67 \%$ dan pertemuan kedua sebesar $83,3 \%$ sedangkan pada siklus II pertemuan pertama sebesar $100 \%$ dan pertemuan kedua sebesar $100 \%$.

\section{Aktivitas Belajar Siswa}

Aktivitas belajar siswa pada siklus I pertama sebesar 66,67\% dan pertemuan kedua sebesar $83,3 \%$ sedangkan pada siklus II pertemuan pertama sebesar $100 \%$ dan pertemuan kedua sebesar $100 \%$.

\section{Pembahasan}

\section{Hasil Belajar Siswa}

Berdasarkan nilai yang diperoleh siswa, guru melakukan analasis untuk menentukan ketuntasan belajar siswa. Hasil Analisis Ketuntasan Belajar Siswa pada Siklus I dan Siklus II dapat dilihat pada tabel 1. berikut:

Tabel 1. Analisis Hasil Belajar IPS Siswa pada Siklus I dan Siklus II

\begin{tabular}{ccccccc}
\hline \multirow{2}{*}{ No. } & \multirow{2}{*}{ Skor } & \multicolumn{2}{c}{ Jumlah Siswa } & \multicolumn{2}{c}{ Persentase (\%) } & \multirow{2}{*}{$\begin{array}{c}\text { Ketuntasan } \\
\text { Belajar }\end{array}$} \\
\cline { 3 - 6 } & & Siklus I & Siklus II & Siklus I & Siklus II & Belum Tuntas \\
\hline 1. & 64 & 10 & 3 & 33,33 & 10 & Tuntas \\
\hline 2. & $65-100$ & 20 & 27 & 66,67 & 90 & \\
\hline 3. & Jumlah & 30 & 30 & 100 & 100 & \\
\hline
\end{tabular}

Tabel 1. menunjukkan bahwa pada pembelajaran siklus I, siswa yang memperoleh nilai antara 0-64 berjumlah 10 orang siswa (33,33\%), siswa yang memperoleh nilai rentang 65-100 berjumlah 20 orang siswa $(66,67 \%)$. Ketuntasan belajar siswa mencapai $66,67 \%$, dimana siswa yang memperoleh nilai $\geq 65$ berjumlah 20 orang siswa sedangkan 10 orang siswa belum mencapai ketuntasan belajar. Pada pembelajaran siklus II, siswa yang memperoleh nilai di bawah 65 berjumlah 3 orang (10\%), siswa yang memperoleh nilai rentang 65-100 berjumlah 27 orang (90\%). Sehingga ketuntasan belajar siswa pada siklus II mencapai $90 \%$. Peningkatan ketuntasan belajar siswa pada penelitian ini dapat dilihat pada gambar 1. berikut: 


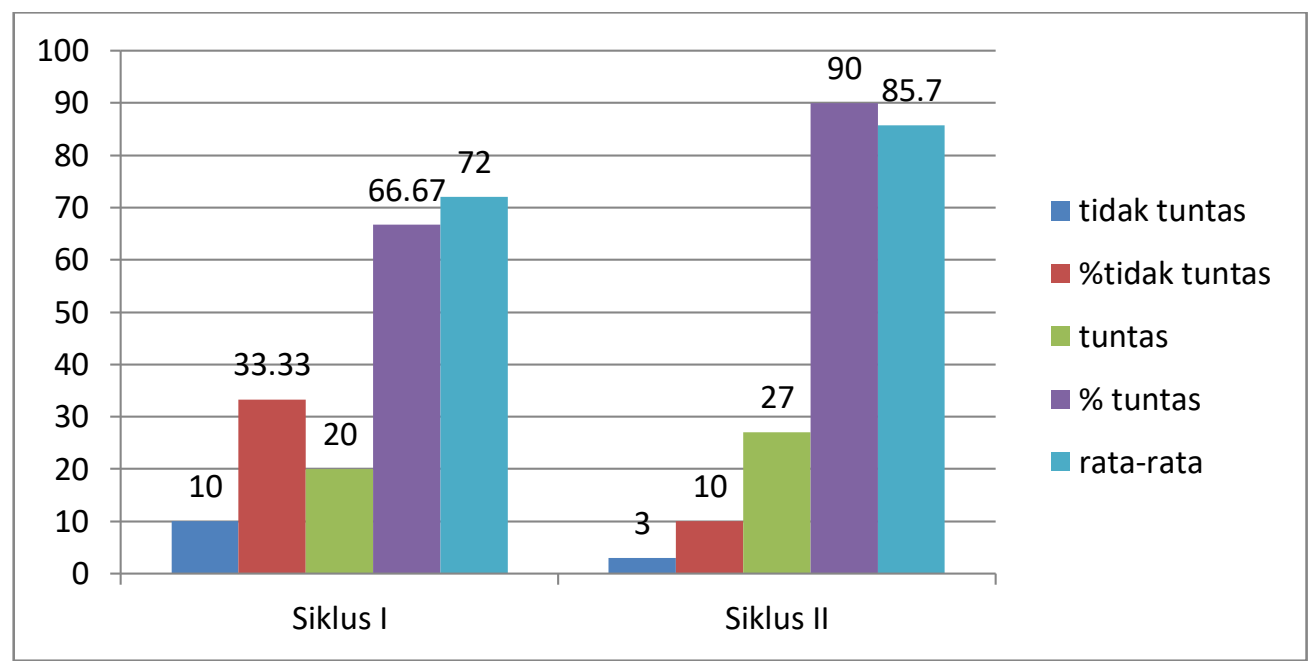

Gambar 1. Grafik Ketuntasan Belajar Siswa Siklus I dan Siklus II

Gambar 1. menunjukkan bahwa siswa yang mencapai ketuntasan belajar pada siklus I berjumlah 20 orang siswa atau $66,67 \%$ dan 7 orang siswa atau 33,33\% belum mencapai ketuntasan belajar. Ketuntasan belajar siswa meningkat pada siklus II dimana 27 orang siswa atau 90\% telah mencapai ketuntasan belajar dan 3 orang siswa atau $10 \%$ belum mencapai ketuntasan belajar. Ketuntasan belajar siswa mengindikasikan bahwa indikator keberhasilan penelitian yang ditetapkan telah tercapai.

Ketuntasan belajar siswa mengindikasikan bahwa indikator keberhasilan penelitian yang ditetapkan telah tercapai. Sedangkan hasil observasi terhadap pelaksanaan pembelajaran bisa dikatakan sempurna, yakni seluruh komponen dalam skenario pembelajaran telah dilaksanakan dengan baik sesuai yang diharapkan. Karena kedua indikator telah tercapai, maka hipotesis tindakan telah tercapai yakni: penerapan model pembelajaran kooperatif tipe Group Investigation dapat meningkatkan hasil belajar IPS siswa pada materi sumber daya alam di kelas IV SD Negeri Tinengi.

Dari hasil evaluasi tersebut menunjukan bahwa usaha dan keberhasilan belajar dipengaruhi oleh berbagai faktor. Hal ini sesuai dengan yang dikemukakan oleh Syah (2010, p.132) bahwa hasil belajar dipengaruhi oleh beberapa faktor yaitu, faktor internal adalah faktor yang berasal dari diri siswa, faktor eksternal adalah faktor yang berasal dari luar diri siswa dan faktor pendekatan belajar yaitu jenis upaya belajar yang meliputi strategi dan metode yang digunakan untuk melakukan pembelajaran. Menurut howard \& Navarro dalam Lyu \& Wang (2018, p.3) mengemukakan bahwa 'Referred learning achievement to learners, in specific learning environment perceiving the intrinsic knowledge and achievement after learning through courses and materials'.

\section{Aktivitas Mengajar Guru}

Selama proses pembelajaran peneliti mengadakan observasi untuk mengetahui kelemahan dan keberhasilan dalam proses pembelajaran. Hal-hal yang observasi aktivitas mengajar guru dan aktivitas belajar siswa pada proses pembelajaran. Hasil observasi aktivitas mengajar guru pada penelitian tindakan pembelajaran menjadi dasar untuk menentukan skor perolehan guru. Skor perolehan guru digunakan untuk menentukan persentase keberhasilan aktivitas mengajar guru.

Dengan adanya kekurangan-kekurangan yang terjadi pada tindakan siklus I, sehingga KAMG pada tindakan I pertemuan 1 hanya mencapai $66,7 \%$ dari keseluruhan kegiatan pembelajaran dan pada pertemuan kedua hanya mencapai $83,3 \%$. Sebelum melaksanakan penelitian pada tindakan II, peneliti mengadakan refleksi bersama observer untuk memperbaiki kekurangan-kekurangan pada tindakan I. 
Pada pelaksanaan tindakan II, keberhasilan aktivitas mengajar guru dan aktivitas belajar siswa sudah menggembirakan bagi peneliti, karena menurut hasil observasi pelaksanaan skenario pembelajaran pada pertemuan pertama aktivitas guru dan siswa mencapai $100 \%$ dan pada pertemuan kedua telah mencapai $100 \%$ baik aktivitas mengajar guru maupun aktivitas belajar siswa. Semua skenario dalam pembelajaran telah terlaksana dengan baik.

\section{Aktivitas Belajar Siswa}

Keberhasilan aktivitas belajar siswa pada tindakan I pertemuan 1, dari 6 skenario pembelajaran yang terlaksana hanya 4 skenario pembelajaran dan pada pertemuan 2 hanya mencapai 5 skenario pembelajaran. Dengan demikian, maka KABS pertemuan I hanya mencapai 66,7\% dan pertemuan 2 mencapai $83,3 \%$. Ketidakberhasilan aktivitas belajar siswa pada tindakan I disebabkan karena peneliti masih terbiasa dengan cara mengajar model lama, dimana siswa dibiarkan sendiri-sendiri dalam mengerjakan tugas atau tidak membimbing kelompok dengan baik dan siswa masih merasa asing dengan belajar dalam kelompok sehingga belum dapat menyesuaikan diri dengan teman dalam kelompoknya. Hal-hal tersebut menyebabkan keaktifan siswa dalam bekerja sama dalam kelompok, partisipasi siswa dalam kelompok untuk menyelesaikan tugas, memberikan gagasan dalam menyelesaikan tugas, dan keberanian siswa dalam mengemukakan pendapat serta tanggung jawab siswa dalam kelompok, tidak sesuai dengan yang diharapkan dalam penerapan model pembelajaran kooperatif Group Investigation. Almeda \& Sahyar (2017, p.76) mengemukakan bahwa 'The principle of reaction in cooperative learning model type Group Investigation is the teacher's role in group investigation is one of counselor, consultant, and friendly critic. Teachers must guide and reflect the group experience over three levels: the problem-solving or task level, the group management level, and the level of individual meaning.' Setelah menerima saran-saran dari observer berdasarkan hasil diskusi pada kegiatan refleksi, maka peneliti mengadakan tindakan siklus II dengan penerapan model pembelajaran kooperatif tipe Group Investigation mata pelajaran IPS materi Sumber daya alam.

Aktivitas belajar siswa dalam kelompok pada tindakan II, sesuai dengan pengamatan peneliti melalui lembar pengamatan kerja kelompok telah berjalan dengan baik. Setiap anggota kelompok sudah dapat berpatisapasi dengan aktif, saling memberi gagasan dengan berbagi tugas dalam menyelesaikan LKS dengan penuh tanggung jawab dan siswa nampak ceria dalam bekerja. Dengan keberhasilan aktivitas mengajar guru dan aktivitas belajar siswa yang sudah cukup baik, maka mempengaruhi hasil belajar siswa.

\section{Simpulan}

1. Terjadi peningkatan hasil belajar yang dicapai siswa kelas IV SD Negeri Tinengi yaitu dari hasil tes evaluasi tindakan siklus I diperoleh bahwa ketuntasan hasil belajar siswa secara klasikal terhadap materi pelajaran sebesar $66,67 \%$ atau sebanyak 20 orang siswa yang memperoleh nilai $\leq 65$ dengan nilai rata-rata 72 kemudian mengalami peningkatan pada hasil tes tindakan siklus II dengan pencapaian hasil belajar siswa secara klasikal terhadap materi sebesar $90 \%$ atau sebanyak 27 siswa memperoleh nilai $\geq 65$ dengan nilai rata-rata 85,7 .

2. Aktivitas mengajar guru mengalami peningkatan dengan rata-rata persentase siklus I sebesar $75 \%$ dan pada siklus II sebesar $100 \%$ atau mengalami peningkatan $25 \%$. Hal ini telah mencapai indikator kinerja yang ditentukan dalam penelitian ini yakni sebesar $80 \%$.

3. Aktivitas belajar siswa juga mengalami peningkatan dengan rata-rata persentase siklus I sebesar $75 \%$ pada pertemuan pertama dan siklus II sebesar $100 \%$ pada pertemuan kedua atau mengalami peningkatan sebesar 25\%. Hal ini telah mencapai indikator kinerja yang ditentukan dalam penelitian ini minimal persentase aktivitas belajar siswa mencapai $80 \%$. 
Jurnal Ilmiah Pembelajaran Sekolah Dasar

Volume 1 Nomor 2 - Agustus 2019,e-ISSN 26560402

Available online at:http://ojs.uho.ac.id/index.php/jipsd

\section{Daftar Pustaka}

Almeda, R. \& Sahyar. Effect of Cooperative Learning Model type Group Investigation Assisted PhET to Students' Conceptual Knowledge.. IOSR Journal of Research \& Method in Education (IOSR-JRME) e-ISSN: 2320-7388,p-ISSN: 2320-737X Volume 7, Issue 4 Ver. III (Jul Aug 2017), PP 75-80. State University of Medan, Indonesia) www.iosrjournals.org

Asma N. 2006. Model Pembelajaran Kooperatif.

Haninu, W. 2010. Peningkatan Hasil Belajar Siswa Kelas Vb SD Negeri 4 Poasia Tahun Ajaran 2005/2006 Melalui Penerapan Model Pembelajaran Kooperatif Tipe Group Investigation. Skripsi. Kendari: FKIP Universitas Halu Oleo.

Iskandar. 2008. Penelitian Tindakan Kelas. Cipayung: Gaung Persada Press.

Ismail. 2002. Model-Model Pembelajaran. Jakarta: Depdiknas.

Jihad A. dan Haris A. 2010. Evaluasi Pembelajaran. Yogyakarta: Multi Pressindo.

Komalasari K. 2010. Pembelajaran Kontekstual. Bandung: PT. Refika Aditama.

Lyu, D. \& Wang, Bei. 2018. Effects of the Application of Computer Network Technology to Guided Discovery Teaching on Learning Achievement and Outcome. EURASIA Journal of Mathematics, Science and Technology Education, 2018, 14(7), 3269-3276. https://doi.org/10.29333/ejmste/91249

Maryati. 2008. Model-model Pembelajaran. Diakses tanggal 28 Mei 2019 dari http:// www. sman1kesamben. com.

Slameto. 2003. Belajar dan Faktor-faktor yang Mempengaruhinya. Jakarta: PT. Rineke Cipta.

Slavin, E.R. 2005. Cooperative Learning. Boston: Allyn Bacon.

Suparno, Paul. 2008. Riset Tindakan Untuk Pendidik. Jakarta: Grasindo

Surina. 2010. Penerapan Model Pembelajaran Cooperative Learning Tipe Group Investigation Untuk Meningkatkan Hasil Belajar IPS Pada Siswa Kelas IVA SD Negeri 2 Mowewe. FKIP Universitas Halu Oleo. Kendari.

Syah, M. 2010. Psikologi Pendidikan Dengan Pendekatan Baru. Bandung: PT. Remaja Rosdakarya.

Trianto, 2010. Mendesain Model Pembelajaran Inovatif-Progresif. Surabaya: Kharisma Putra Utama. 